\title{
Rocinela signata (Isopoda: Aegidae) parasitizing the gills of the spotted goatfish Pseudupeneus maculatus (Actinopterygii: Mullidae) in Northeastern Brazil
}

\author{
LUCAS CARDOSO ${ }^{1}$, MAURÍCIO L. MARTINS ${ }^{1}$, JÉSSICA E.S. DE AQUÍNO GOLZIO ${ }^{2}$, CAROLINA N.C. \\ BOMFIM $^{3}$, RICARDO L.M. DE OLIVEIRA ${ }^{3}$, LEILANE B.G. DOS SANTOS ${ }^{3}$ and ANA CAROLINA F. LACERDA ${ }^{2}$ \\ ${ }^{1}$ Laboratório de Sanidade de Organismos Aquáticos/AQUOS, Departamento de Aquicultura, Universidade Federal \\ de Santa Catarina/UFSC, Rodovia Admar Gonzaga, 1346, Itacorubi, 88040-900 Florianópolis, SC, Brazil \\ ${ }^{2}$ Departamento de Sistemática e Ecologia, Universidade Federal da Paraíba/UFPB, \\ Campus I, Cidade Universitária, s/n, 58051-900 João Pessoa, PB, Brazil \\ ${ }^{3}$ Departamento de Engenharia de Pesca e Aquicultura, Centro de Ciências Agrárias Aplicadas, Universidade Federal \\ de Sergipe /UFSE, Rua Marechal Rondon, s/n, Jardim Rosa Elze, 49100-000 São Cristóvão, SE, Brazil
}

Manuscript received on September 10, 2015; accepted for publication on May 12, 2016

\begin{abstract}
Parasitic isopods of fishes usually show wide distribution and low host specificity. This study investigated the occurrence of gill parasites in 120 specimens of spotted goatfish Pseudupeneus maculatus, marine fish of great economic importance for fishery community. The fish were captured monthly in the Coast of Pernambuco State, Northeast Brazil, between October 2012 and September 2013. Eleven isopods were found and identified as Rocinela signata. We observed lower infections in the gills of P. maculatus (prevalence $8.3 \%$, mean intensity $1.6 \pm 0.3$ and mean abundance $0.1 \pm 0.3$ ) when compared to other studies of different host fishes from geographically close locations. This parasite has been reported from a wide variety of fish species, not only in Brazil, but also in the eastern Atlantic and the Pacific oceans. This is the first report of $R$. signata in spotted goatfish.
\end{abstract}

Key words: coast of Pernambuco, crustacean, marine fish, parasitism.

\section{INTRODUCTION}

Isopods are crustaceans that present a great variety of shapes and sizes, occurring in different habitats, from the bottom of the ocean to mountain regions (Wilson 2008); their marine representatives are important constituents of the invertebrate fauna of this ecosystem, especially considering their different roles in the marine foodchain (Riseman

Correspondence to: Ana Carolina Figueiredo Lacerda

E-mail: acflacerda@dse.ufpb.br and Brusca 2002). Among the isopods, members of the family Aegidae Dana, 1853 are known for its association to the body surface of fish and sponges (Porifera); comprising isopods with different modes of life, from free living organisms to obligatory parasites (Brusca 1983). Their species are widely distributed throughout the oceans, from tropical to polar waters, from shallow regions to great depths (Bruce 2001, 2009).

The family Aegidae comprises five genera and approximately 107 described species; the genus 
Rocinela Leach, 1818 in this family is cosmopolitan and includes described 40 species (Brusca 1983). Rocinela signata (Schiodte and Meinert 1879) can be found either in the free-living form in the bottom of the ocean, or as a fish parasite. The species has a wide distribution on the West Atlantic Ocean, from Florida to Southern Brazil, and most of the records are from coastal regions (Brusca and France 1992). This species differs from its congeners by presenting the image of a pigmented and inverted "W" on its pleotelson, an important characteristic considered for its identification (Moreira 1977).

When parasitizing fish, $R$. signata is mostly found in the oral cavity, gills and tegument of several species, including some economically important hosts (Garzón-Ferreira 1990, Bunkley-Williams et al. 2006). Its attachment apparatus and feeding activity causes injuries to the fish and predisposes the hosts to secondary infections, and reducing its growth rate (Moreira 1977, Cavalcanti et al. 2012). In addition to the damages to the host fitness and health, the parasite affects the appearance of the fish and consequently their commercial value (Ravichandran et al. 2010).

Spotted goatfish known as "saramunete" in Northeastern Brazil Pseudupeneus maculatus (Bloch, 1793) (Mullidae) forages on the bottom, and is commonly found in coral reefs on the West Atlantic from the Bermudas through New Jersey, USA to Santa Catarina, South Brazil (HostimSilva et al. 2006). They are versatile predators that use their camouflage to capture small fishes and crustaceans on the substrates mixed by sand, gravel and stones (Krajewski et al. 2006, Sazima et al. 2006). Pseudopeneus maculatus is not considered to be threatened at present, being classified in the IUCN Category of Least Concern (Dooley et al. 2015). In Brazil, they are abundant in the Northeastern coast, mainly in the State of Pernambuco where they are commercially valued and have their exploitation destined to the internal and external market (United States and Europe) (Santana et al. 2006, Lima et al. 2008).

Pseudupeneus maculatus is generally captured in the continental platforms in shallow waters, part of a coastal tropical system from which dozens of people depend (Campos and Oliveira 2001, Rocha et al. 1998). The stocks of $P$. maculatus have been impacted by the capture of immature specimens in hatchery areas, compromising the biological and fishery recruitment of the species (Lessa et al. 2004).

The aim of this study was to report for the first time the occurrence of $R$. signata on the gills of the spotted goatfish P. maculatus captured by artisanal fishermen in the Brazilian Northeast. The global and Brazilian distributions of the parasite are also discussed.

\section{MATERIALS AND METHODS}

A total of 120 fish with $140.2 \pm 45.1 \mathrm{~g}$ weight (47.5$262.1)$ and $21.5 \pm 2.1 \mathrm{~cm}$ total length (16-27) were collected by fishermen in three intervals of fishing of the Coast of Pernambuco State, Northeast Brazil for parasitological analysis: Site $1\left(7^{\circ} 37^{\prime} 28.43^{\prime \prime} \mathrm{S}\right.$ $34^{\circ} 1$ '10.24”W) - approximately 50 nautical miles $(93 \mathrm{Km})$ from the municipality of Goiana; Site 2 (7'50.34'S 3443'41.73”W) - metropolitan region of Recife, always in the isobate of $45.7 \mathrm{~m}$ from the shore ( 15 to $20 \mathrm{~m}$ depth); Site 3 (8॰54'41.79”'S $\left.33^{\circ} 57^{\prime} 23.45^{\prime \prime} \mathrm{W}\right)$ - approximately 70 nautical miles from the shore $(130 \mathrm{Km})$ close to the municipality of São José da Coroa Grande.

Fish were individually identified and kept on ice in thermal boxes for biometry and posterior necropsy. The gonads were exposed and observed to determination of sex and the gills were collected and fixed in alcohol 70\%, identified and shaked for parasite detachment according to Eiras et al. (2006) and Jerônimo et al. (2011).

The isopods found were analyzed under stereomicroscope and identified according 
to Brusca and France (1992). Parasitological descriptors followed the recommendations of Bush et al. (1997).

\section{RESULTS AND DISCUSSION}

Among the 120 (64 males, 50 females and 6 indeterminate sex) specimens of $P$. maculatus that were examined (Figure 1), the gills of 10 were parasitized ( 6 on males, 4 on females and 1 on indeterminate sex) by at least one of the eleven individuals of $R$. signata (Figure 2), with prevalence $8.3 \%$, mean intensity of infestation of $1.1 . \pm 0.3$ varying from 1 to 2 parasites per host and mean abundance of $0.1 \pm 0.3$. Measurements $(\mathrm{mm})$ were based on seven specimens: $11.0 \pm 3.6$ (4.013.0) long and 3.0 \pm 1.2 (1.5-4.0) wide.

The hosts reported for $R$. signata in Brazil are listed in Table I. In other countries, the parasite was reported from Dasyatis americana Hildebrand \& Schroeder, 1928 and Dasyatis guttata (Bloch \& Schneider, 1801) from Colombia (Williams Jr et al. 1994); in D. guttata, Haemulon aurolineatum Cuvier, 1830, H. steindachneri (Jordan \& Gilbert, 1882), Orthopristis ruber (Cuvier, 1830) and Heteropriacanthus cruentatus (Lacepède, 1801) from Venezuela (Bunkley-Williams et al. 2006); in Epinephelus itajara (Lichtenstein, 1822) and $L$. analis from Tortugas; L. analis and Mycteroperca venenosa (Linnaeus, 1758) from the U.S. Virgin Islands; Archosargus probatocephalus (Walbaum,
1792), L. analis, Lutjanus buccanella (Cuvier, 1828), Balistes vetula Linnaeus, 1758, Calamus calamus (Valenciennes, 1830) from Bahamas; Haemulon flavolineatum (Desmarest, 1823), Lachnolaimus maximus (Walbaum, 1792), Sparisoma viride (Bonnaterre, 1788) from Jamaica; Galeocerdo cuvieri (Péron \& Lesueur, 1822) from Mexico; Dasyatis americana, Ginglymostoma cirratum (Bonnaterre, 1788) from Puerto Rico, Calamus bajonado (Bloch \& Schneider, 1801), Calamus penna (Valenciennes, 1830), Bothus lunatus (Linnaeus, 1758), B. vetula, Caranx sp., Sphyraena barracuda (Edwards, 1771), L. maximus, L. analis from Belize; O. ruber, H. steindachneri from Venezuela; C. penna from Surinam and in Epinephelus morio (Valenciennes, 1828), Lutjanus blackfordi [=Lutjanus campechanus (Poey, 1960)], Mycteroperca bonaci (Poey, 1860) and Raja eglanteria Bosc, 1800 from the Gulf of Mexico (Kensley and Schotte 1989). These copepods were also found in the gills of Haemulon sciurus (Shaw, 1803) from Carrie Bow Cay, Belize (Williams Jr et al. 2009).

Regarding the levels of infestation, the present study found similar prevalence and intensities to those reported previously. The prevalence of the parasite found in this study was slightly higher than that reported by Luque et al. (2002), Cavalcanti et al. (2013), Hermida et al. (2014) and CarvalhoSouza et al. (2009) (Table I).

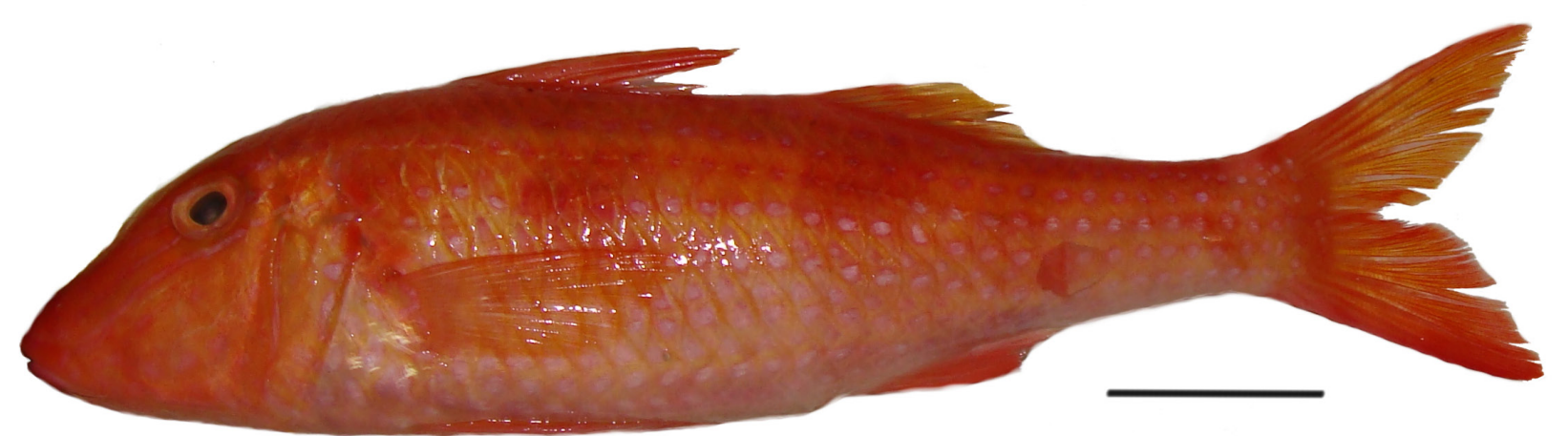

Figure 1 - The host Pseudupeneus maculatus, from the Coast of Pernambuco State, Northeast Brazil. Scale bar: $3 \mathrm{~cm}$. 


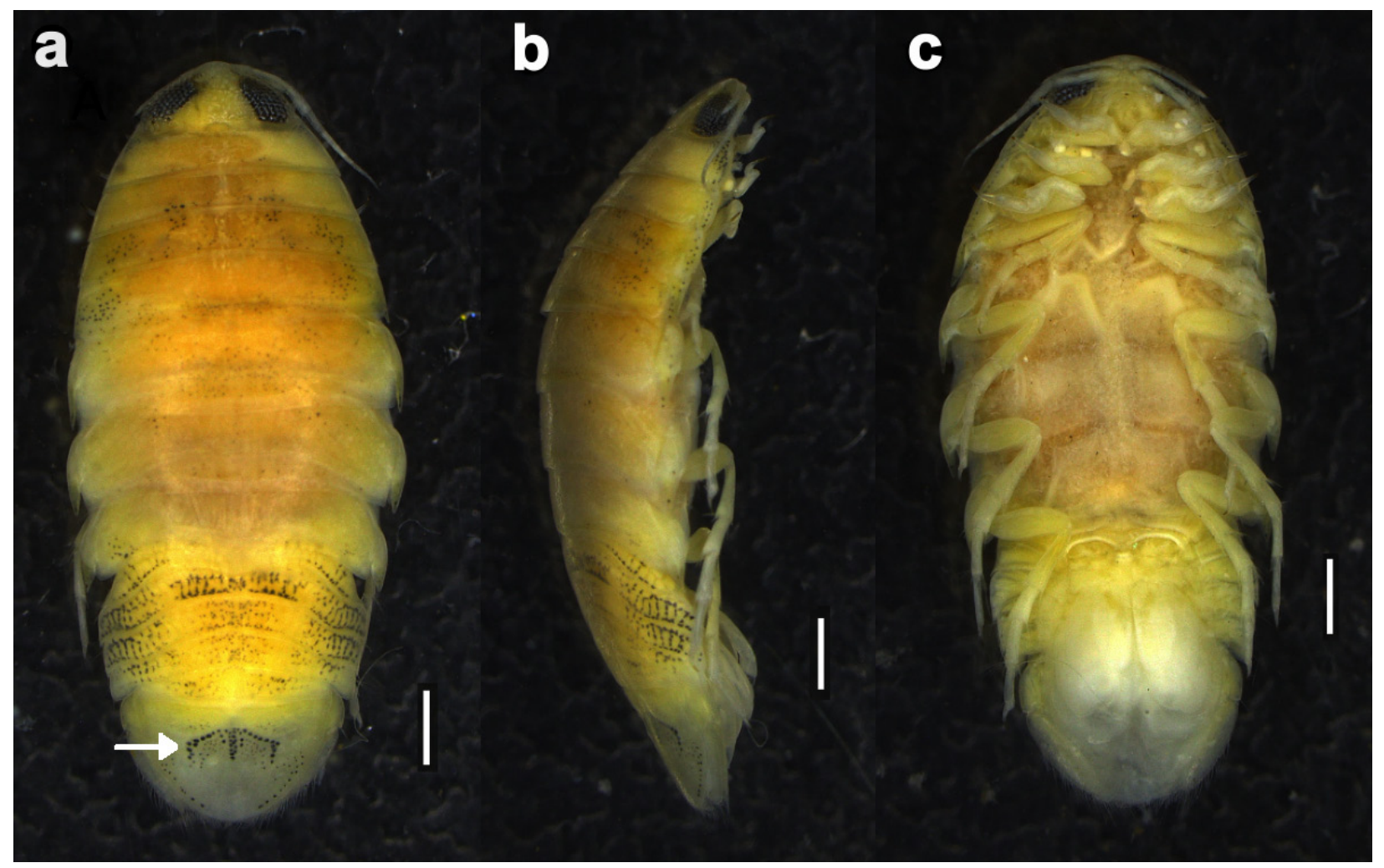

Figure 2 - Rocinela signata from the gills of Pseudupeneus maculatus, Northeastern Brazil. a - dorsal view; b - lateral view; c ventral view. The arrow indicates the pigmented inverted $\mathrm{W}$ on the pleotelson. Scale bar: $1 \mathrm{~mm}$.

TABLE I

Hosts, Locality, Prevalence (P), mean intensity (MI), and references of the records of Rocinela signata parasitizing fish in Brazil.

\begin{tabular}{lcccc}
\hline \multicolumn{1}{c}{ Host } & Locality (State) & P(\%) & MI & Reference \\
\hline $\begin{array}{l}\text { Archosargus rhomboidalis (Linnaeus, 1758) (Sparidae) } \\
\text { Caranx crysos (Mitchill, 1815) (Carangidae) }\end{array}$ & Rio Grande do Norte & 18.2 & - & Lima et al. 2011 \\
Chloroscombrus chrysurus (Linnaeus, 1766) (Carangidae) & Rio Grande do Norte & 4 & - & Lima et al. 2011 \\
Cynoscion leiarchus (Cuvier, 1830) (Sciaenidae) & São Paulo & - & - & Moreira 1972 \\
$\begin{array}{l}\text { Lutjanus analis (Cuvier, 1828) (Lutjanidae) } \\
\text { Lutjanus synagris (Linnaeus, 1758) (Lutjanidae) }\end{array}$ & Alagoas & 3.3 & 1 & Hermida et al. 2014 \\
$\begin{array}{l}\text { Mullus argentinae Hubbs \& Marini, 1933 (Mullidae) } \\
\text { Oligoplites saliens (Bloch, 1793) (Carangidae) }\end{array}$ & Rio de Janeiro & 3 & 1 & Luque et al. 2002 \\
$\begin{array}{l}\text { Pseudupeneus maculatus (Bloch, 1793) (Mullidae) } \\
\text { Scomberomorus brasiliensis Collette, Russo \& Zavala- }\end{array}$ & Bahia & 4.6 & 1 & Carvalho-Souza et al. \\
Camin, 1978 (Scombridae) & Pernambuco & 8.3 & 1.1 & Present study \\
$\begin{array}{l}\text { Sparisoma frondosum (Agassiz, 1831) (Scaridae) } \\
\text { Trichiurus lepturus Linnaeus, 1758 (Trichiuridae) }\end{array}$ & Rio Grande do Norte & 37.5 & 2.9 & Cavalcanti et al. 2012 \\
& Bahia & 8.3 & 1 & Carvalho-Souza et al. \\
\end{tabular}


Lima et al. (2005) reported higher prevalence (44.44\%) of $R$. signata in S. brasiliensis from the Rio Grande do Norte, region close to Pernambuco, the same region where the present study was performed. Similarly to Lima et al. (2005), 37.5\% prevalence was found by Cavalcanti et al. (2012) in S. frondosum from Rio Grande do Norte with mean intensity 2.58 and abundance 0.97 in male and female fish in both rainy and dry seasons. Apart from the highest prevalence of $R$. signata observed in H. steindachneri (20\%), Bunkley-Williams et al. (2006) have reported the lowest ones in $H$. aurolineatum (0.45\%), O. ruber (0.49\%) and in $H$. cruentatus $(0.22 \%)$.

Although the parasite can be found parasitizing several fish species, its preference for some species must not to be dismissed. Isopods of the family Aegidae are temporary or facultative parasites with low host specificity (Brusca 1983). They feed on blood and are generally found associated with the gill chamber of marine fish of economic importance (Hermida et al. 2014, Bunkley-Williams et al. 2006). In aquaculture, for example, fish parasitized by these isopods exihibit respiratory problems, low growth rate and are more susceptible to secondary infections due to opened wounds (Bunkley-Williams and Williams Jr 1998). However, the effects of these isopods on the host health and survival (e.g., increased predation) in the nature remains unknown, and it might be strongly associated to their modes of attachment and injury caused to the host tissue.

\section{ACKNOWLEDGMENTS}

The authors thank the Conselho Nacional de Desenvolvimento Científico e Tecnológico (CNPq) for Research grant to M.L. Martins (CNPq 305869/2014-0), and the Coordenação de Aperfeiçoamento de Pessoal de Nível Superior (CAPES) for master scholarship to J.E.S.A. Golzio and Dr. M. Kent (Department of Microbiology, OSU, Corvallis, OR, USA) for language revision.

\section{REFERENCES}

BRUCE NL. 2001. Marine isopod crustaceans in New Zealand. NIWA Water \& Atmosphere 9(3): 12-13.

BRUCE NL. 2009. The Marine Fauna of New Zealand: Isopoda, Aegidae (Crustacea). NIWA Biodiversity Memoir 122: 1-252.

BRUSCA RC. 1983. A monograph on the isopod family Aegidae in the tropical eastern Pacific. I. The genus Aega. Allan Hancock Monogr Mar Biol 12: 1-39.

BRUSCA RC AND FRANCE SC. 1992. The genus Rocinela (Crustacea: Isopoda: Aegidae) in the tropical eastern Pacific. Zool J Linn Soc-Lond 106: 231-275.

BUNKLEY-WILLIAMS L AND WILLIAMS JR EH. 1998. Isopods associated with fishes: a synopsis and corrections. J Parasitol 84(5): 893-896.

BUNKLEY-WILLIAMS L, WILLIAMS JR EH AND BASHIRULLAH AKM. 2006. Isopods (Isopoda: Aegidae, Cymothoidae, Gnathiidae) associated with Venezuelan marine fishes (Elasmobranchii, Actinopterygii). Rev Biol Trop 54(3): 175-188.

BUSH AO, LAFFERTY KD, LOTZ JM AND SHOSTAK AW. 1997. Parasitology meets ecology on its own terms: Margolis et al. Revisited. J Parasitol 83(4): 575-583.

CAMPOS CEC AND OLIVEIRA JEL. 2001. Caracterização biométrica e merística do saramunete, Pseudupeneus maculatus (Osteichthyes: Mullidae), em Ponta das Pedras, Pernambuco. Bol Inst Pesca 27(2): 185-189.

CARVALHO-SOUZA GF, SOUZA NETO JR, ALELUIA FT, NASCIMENTO IA, BROWNE-RIBEIRO H, SANTOS RC AND TINÔCO MS. 2009. Occurrence of isopods ectoparasites in marine fish on the Cotegipe Bay, northeastern Brazil. Mar Biodivers Rec 2: 1-4.

CAVALCANTI ETS, NASCIMENTO SKS, BARROS NHC AND CHELLAPPA S. 2012. Occurrence of the isopod parasite Rocinela signata (Isopoda: Aegidae) on marine fish Sparisoma frondosum (Osteichthyes: Scaridae). J Mar Biol Assoc UK 5(1): 1-4.

CAVALCANTI ETS, NASCIMENTO WS, TAKEMOTO RM, ALVES LC AND CHELLAPPA S. 2013. Ocorrência de crustáceos ectoparasitos no peixe ariacó, Lutjanus synagris (Linnaeus, 1758) nas águas costeiras do Rio Grande do Norte, Brasil. Biota Amazônia 3(1): 94-99.

DOOLEY J, AIKEN KA, COLLETTE B, MARECHAL J, PINA AMARGOS F, KISHORE R AND SINGHRENTON S. 2015. Pseudupeneus maculatus. IUCN 2016. The IUCN Red List of Threatened Species. Version 20161. $<$ http://www.iucnredlist.org $>$. Downloaded on 30 June 2016. 
EIRAS JC, TAKEMOTO RM AND PAVANELLI GC. 2006. Métodos de estudo e técnicas laboratoriais em parasitologia de peixes. $2^{\mathrm{a}}$ ed., EDUEM, Maringá, Brasil, 199 p.

GARZÓN-FERREIRA J. 1990. An isopod, Rocinela signata (Crustacea: Isopoda: Aegidae), that attacks humans. B Mar Sci 46(3): 813-815.

HERMIDA M, CARVALHO BFL, CRUZ C AND SARAIVA A. 2014. Parasites of the Mutton Snapper Lutjanus analis (Perciformes: Lutjanidae) in Alagoas, Brazil. Rev Bras Parasitol Vet 23(1): 241-243.

HOSTIM-SILVA M, ANDRADE AB, MACHADO LF, GERHARDINGER LC, DAROS FA, BARREIROS JP AND GODOY E. 2006. Peixes de Costão Rochoso de Santa Catarina. I. Arvoredo. Editora UNIVALI, Florianópolis, Brasil, $135 \mathrm{p}$.

JERÔNIMO GT, MARTINS ML, ISHIKAWA MM, VENTURA AS AND TAVARES-DIAS M. 2011. Métodos para coleta de parasitos. Circular técnica EMBRAPA, Macapá (39): 1-6.

KENSLEY B AND SCHOTTE M. 1989. Guide to the marine isopod crustaceans of the Caribbean. Smithsonian Institution Press, Washington, D.C., 308 p.

KRAJEWSKI JP, BONALDO RM, SAZIMA C AND SAZIMA I. 2006. Foraging activity and behavior of two goatfish species (Perciformes: Mullidae) at Fernando de Noronha Archipelago, tropical West Atlantic. Environ Biol Fish 77: 1-8.

LESSA RP, NÓBREGA MF AND BEZERRA JUNIOR JL (Orgs). 2004. Dinâmica de Populações e Avaliação de Estoques dos Recursos Pesqueiros da Região Nordeste. Universidade Federal Rural de Pernambuco, Departamento de Pesca, Laboratório de Dinâmica de Populações Marinhas (DIMAR), Programa de Avaliação do Potencial Sustentável dos Recursos Vivos da Zona Econômica Exclusiva (REVIZEE), Sub-Comitê Regional Nordeste (SCORE - NE). Volume II, Recife, 246 p.

LIMA JTAX, CHELLAPPA S AND THATCHER VE. 2005. Lironeca redmanni Leach (Isopoda, Cymothoidae) e Rocinela signata Schioedte \& Meinert (Isopoda, Aegidae), ectoparasitos de Scomberomorus brasiliensis Collette, Russo \& Zavala-Camin (Ostheichthyes, Scombridae) no Rio Grande do Norte, Brasil. Rev Bras Zool 22(4): 11041108.

LIMA JTAX, FREITAS MDF, FERNANDES BLF AND BEZERRA JUNIOR JTA. 2011. Preferência de diferentes habitats do parasita Rocinela signata em peixes marinhos Archosargus rhomboidalis e Chloroscombrus chrysurus no litoral do Rio Grande do Norte. Revista Eletrônica Científica Centauro 2: 23-27.
LIMA MM, TEIXEIRA WC, RAMOS RAN, LIMA AMA, ALVES LC AND FAUSTINO MAG. 2008. Ocorrência de ovos de Capillaria sp. em filé de peixe saramunete (Pseudupeneus maculatus) comercializado na Região Metropolitana de Recife-PE/Brasil. Med Vet-Recife 2(1): 35-37.

LUQUE JL, PORROZZI F AND ALVES DR. 2002. Community ecology of the metazoan parasites of Argentine Goatfish, Mullus argentinae (Osteichthyes: Mullidae), from the coastal of the state of Rio de Janeiro, Brazil. Rev Bras Parasitol Vet 11(1): 33-38.

MOREIRA PS. 1972. Species of marine isopoda (Crustacea, Peracarida) from Southern Brazil. Bol Inst Oceanogr 21: 163-179.

MOREIRA PS. 1977. Occurrence and ecological notes on Rocinela signata (Isopoda, Flabellifera) of Brazil. Boldo Inst Oceanogr 26: 293-301.

RAVICHANDRAN S, RAMESHKUMAR G AND BALASUBRAMANIAN T. 2010. Infestation of isopod parasites in commercial marine fishes. J Parasit Dis 34(2): 97-98.

RISEMAN SF AND BRUSCA RC. 2002. Taxonomy, phylogeny and biogeography of Politolana Bruce, 1981 (Crustacea: Isopoda: Cirolanidae). Zool J Linn Soc-Lond 134: 57-140.

ROCHA LA, ROSA IL AND ROSA RS. 1998. Peixes recifais da costa da Paraíba, Brasil. Rev Bras Zool 15(2): 553-566.

SANTANA FM, MORIZE E AND LESSA R. 2006. Age and growth of the spotted goatfish, Pseudupeneus maculatus (Bloch, 1793) in Brazil, validated through marginal increment and oxytetracycline dyes in the sagittae. J Appl Ichthyol 22: 132-137.

SAZIMA C, KRAJEWSKI JP, BONALDO RM AND GUIMARÃES JR. 2006. The goatfish Pseudupeneus maculatus and its follower fishes at an oceanic island in the tropical West Atlantic. J Fish Biol 69: 883-891.

WILLIAMS JR EH, BUNKLEY-WILLIAMS L AND DOWGIALLO MJ. 2009. Consistent attachment by the Monogram Isopod, Rocinela signata (Isopoda: Aegidae) on the Bluestriped Grunt, Haemulon sciurus at Carrie Bow Cay, Belize and a Host List. Caribbean Coral Reef Ecosystems, National Museum of Natural History, CCRE Reports, 31-32.

WILLIAMS JR EH, BUNKLEY-WILLIAMS L AND SANNER CJ. 1994. New host and locality records for copepod and isopod parasites of Colombian marine fishes. J Aquat Anim Health 6: 362-364.

WILSON GDF. 2008. Global diversity of Isopod crustaceans (Crustacea, Isopoda) in freshwater. Hydrobiologia 595: 231-240. 